\title{
Atopic Dermatitis: Update on Pathogenesis and Comorbidities
}

\author{
Jonathan I. Silverberg • Nanette B. Silverberg
}

Published online: 15 September 2012

(C) Springer Science+Business Media, LLC 2012

\begin{abstract}
Atopic dermatitis (AD) is a significant cause of morbidity and healthcare costs in the United States and worldwide. The prevalence of $\mathrm{AD}$ in childhood is rising in the United States and other developed countries for reasons that are not well understood. Similarly, the prevalences of obesity and diabetes are on the rise, which might be contributing toward increased AD. This article reviews the association between $\mathrm{AD}$ and other atopic disorders with obesity and diabetes. Furthermore, recently recognized AD comorbidities, including fatty liver disease and erectile dysfunction, are reviewed. Potential mechanisms for the association between $\mathrm{AD}$ and metabolic disorders are discussed.
\end{abstract}

Keywords Atopic dermatitis $\cdot$ Hand dermatitis $\cdot$ Eczema . Asthma $\cdot$ Rhinoconjunctivitis $\cdot$ Food allergies $\cdot$ Atopy $\cdot \operatorname{IgE} \cdot$ Comorbidities $\cdot$ Obesity $\cdot$ Diabetes $\cdot$ Fatty liver $\cdot$ Erectile dysfunction · Filaggrin - Innate immune system $\cdot$ Cutaneous infections

\begin{tabular}{ll}
\multicolumn{2}{l}{ Abbreviations } \\
AD & Atopic dermatitis \\
BMI & Body mass index \\
FLG & Filaggrin \\
TLR & Toll-like receptor \\
IL & Interleukin \\
RAST & Radioallergosorbent test \\
IgE & Immunoglobulin E \\
NHANES & National Health and Nutrition Examination \\
& Survey \\
ISAAC & The International Study of Asthma and \\
& Allergies in Childhood
\end{tabular}

J. I. Silverberg $\cdot$ N. B. Silverberg $(\bowtie)$

Department of Dermatology,

St. Luke's-Roosevelt Hospital and Beth Israel Medical Centers,

Suite 11D, 1090 Amsterdam Avenue,

New York, NY 10025, USA

e-mail: Nsilverb@chpnet.org

\section{Introduction}

Atopic dermatitis (AD) is a significant cause of morbidity and healthcare costs in the United States. The annual direct healthcare cost of AD in the United States is estimated to be 900 million U.S. dollars per year [1]. The prevalence of AD in childhood was $2-3 \%$ before $1960,9-12 \%$ after 1970 , and is now as high as $20 \%[2,3]$. The reasons for this increase are not well understood. There are new recent trends in the prevalence of $\mathrm{AD}$ and its comorbidities, which we review in this article (summarized in Table 1).

\section{Pathogenesis of AD}

The pathogenesis of $\mathrm{AD}$ is quite complex, involving an interaction between genetics and environmental factors. This is highlighted by a recent population-based study of U.S. children that found several socioeconomic risk factors for higher prevalence of AD in the United States, including black race, metropolitan living, and household education level greater than high school [4•].

The recent discovery of filaggrin gene (FLG) polymorphisms in the pathogenesis of $\mathrm{AD}$ was a significant breakthrough in our understanding of $\mathrm{AD}$ [5-12]. FLG mutations have thus far been found in up to $20 \%$ of $\mathrm{AD}$ patients and may be associated with greater severity [9, 13]. SPINK5, a serine protease inhibitor involved in the regulation of stratum corneum thickness and function, is another gene of interest in AD. SPINK5 mutations are found in $\mathrm{AD}$ associated with Netherton's syndrome [14] and also have been found in some subsets of $\mathrm{AD}$ and are felt to confer risk of maternal transmission of $\mathrm{AD}[15$, 16]. However, several observations suggest that genetic mutations resulting in barrier impairment are not the only pathogenic factor in AD. First, FLG and other skinbarrier gene mutations have been found in a minority of $\mathrm{AD}$ subjects. Second, genetic mutations alone would not 
Table 1 Studies of the relationship between atopic dermatitis/eczema- and obesity-related comorbidities

\begin{tabular}{|c|c|c|c|c|}
\hline Comorbidity & Study & Data source & Outcome measures & Findings \\
\hline \multirow[t]{12}{*}{ Obesity } & $\begin{array}{l}\text { Silverberg et al. } \\
{[85 \bullet \bullet}\end{array}$ & $\begin{array}{l}\text { Retrospective pediatric } \\
\text { practice-based study }\end{array}$ & $\begin{array}{l}\text { Atopic dermatitis prevalence, } \\
\text { severity and pediatrician visits }\end{array}$ & $\begin{array}{l}\text { Association between obesity and atopic } \\
\text { dermatitis prevalence, severity and } \\
\text { healthcare utilization }\end{array}$ \\
\hline & $\begin{array}{l}\text { Silverberg et al. } \\
\text { [86] }\end{array}$ & $\begin{array}{l}\text { Retrospective adult allergy } \\
\text { practice-based study }\end{array}$ & $\begin{array}{l}\text { Atopic dermatitis prevalence (history } \\
\text { of eczema, family history of atopic } \\
\text { disease, positive skin-prick testing) }\end{array}$ & $\begin{array}{l}\text { Association between obesity and } \\
\text { atopic but not nonatopic dermatitis } \\
\text { prevalence in adults }\end{array}$ \\
\hline & Murray et al. $[87 \bullet \bullet]$ & Prospective birth cohort study & $\begin{array}{l}\text { Physician diagnosis of eczema in } \\
\text { past } 12 \text { months }\end{array}$ & $\begin{array}{l}\text { Association between obesity and } \\
\text { physician diagnosed atopic } \\
\text { dermatitis at age } 5 \text { and } 8 \text { years }\end{array}$ \\
\hline & $\begin{array}{l}\text { Suárez-Varela et al. } \\
\text { [89••] }\end{array}$ & $\begin{array}{l}\text { Spanish subset of ISAAC } \\
\text { Phase } 3\end{array}$ & $\begin{array}{l}\text { Itchy rash in the past } 12 \text { months and in the } \\
\text { folds of the elbows, behind the knees, in } \\
\text { front of the ankles, under the buttocks, } \\
\text { or around the neck, ears, or eyes }\end{array}$ & $\begin{array}{l}\text { Association between obesity and } \\
\text { prevalence of atopic dermatitis }\end{array}$ \\
\hline & $\begin{array}{l}\text { Kusunoki et al. } \\
{[88 \bullet \bullet}\end{array}$ & Japanese questionnaire study & $\geq 3 / 21$ symptoms of atopic dermatitis & $\begin{array}{l}\text { Association between obesity and } \\
\text { prevalence and severity of atopic } \\
\text { dermatitis }\end{array}$ \\
\hline & Lee et al. [84] & Korean questionnaire study & $\begin{array}{l}\text { Twelve-month prevalences of the } \\
\text { symptoms of flexural eczema }\end{array}$ & $\begin{array}{l}\text { Association between BMI and } \\
\text { increased prevalence of flexural } \\
\text { eczema }\end{array}$ \\
\hline & Yao et al. [90] & Taiwanese questionnaire study & $\begin{array}{l}\text { Ever- and current- history of eczema } \\
\text { (using ISAAC questionnaire) }\end{array}$ & $\begin{array}{l}\text { Association of obesity with ever- and } \\
\text { current-atopic dermatitis }\end{array}$ \\
\hline & $\begin{array}{l}\text { Anveden Berglind } \\
\text { et al. [97] }\end{array}$ & Swedish questionnaire study & Hand eczema in past 12 months & $\begin{array}{l}\text { Association between obesity and } \\
\text { hand eczema in men and women }\end{array}$ \\
\hline & Mai et al. [59] & $\begin{array}{l}\text { Swedish subset of ISAAC: } \\
\text { Phase } 2 \text { study }\end{array}$ & $\begin{array}{l}\text { Current wheeze, number of wheezing episodes in past } \\
12 \text { months, hypertonic saline provocation }\end{array}$ & $\begin{array}{l}\text { Association between overweight/ } \\
\text { obesity and eczema in wheezing } \\
\text { children }\end{array}$ \\
\hline & $\begin{array}{l}\text { Von Kries et al. } \\
\text { [58] }\end{array}$ & Bavarian questionnaire study & Prevalence of doctor diagnosed eczema & $\begin{array}{l}\text { No association between overweight/ } \\
\text { obesity and lifetime prevalence of } \\
\text { eczema }\end{array}$ \\
\hline & Vlaski et al. [83] & $\begin{array}{l}\text { Republic of Macedonia subset } \\
\text { of ISAAC: Phase } 3 \text { study }\end{array}$ & Self-report of eczema & $\begin{array}{l}\text { No association between overweight/ } \\
\text { obesity and lifetime prevalence of } \\
\text { eczema }\end{array}$ \\
\hline & Violante et al. [82] & $\begin{array}{l}\text { Mexico City subset of ISAAC } \\
\text { Phase } 3 \text { study }\end{array}$ & Lifetime prevalence of eczema & $\begin{array}{l}\text { Association between obesity and } \\
\text { lower prevalence of eczema }\end{array}$ \\
\hline \multirow[t]{6}{*}{ Diabetes } & $\begin{array}{l}\text { Rosenbauer et al. } \\
\text { [102] }\end{array}$ & $\begin{array}{l}\text { German population-based } \\
\text { study }\end{array}$ & $\begin{array}{l}\text { New clinical diagnosis of type } 1 \text { diabetes and positive } \\
\text { response to atopic dermatitis on questionnaire }\end{array}$ & $\begin{array}{l}\text { Inverse association between type } 1 \\
\text { diabetes and prevalence of AD in } \\
\text { childhood }\end{array}$ \\
\hline & $\begin{array}{l}\text { Thomsen et al. } \\
\text { [103] }\end{array}$ & Danish twin study & $\begin{array}{l}\text { Hospital discharge diagnosis of type } 1 \text { diabetes } \\
\text { and positive response to atopic dermatitis on } \\
\text { questionnaire }\end{array}$ & $\begin{array}{l}\text { Inverse association between type } 1 \\
\text { diabetes and prevalence of AD }\end{array}$ \\
\hline & Stene et al. [104] & Case-control study & $\begin{array}{l}\text { Diagnosis of type } 1 \text { diabetes from the Norwegian } \\
\text { childhood diabetes registry and positive response to } \\
\text { physician-diagnosed eczema }\end{array}$ & $\begin{array}{l}\text { Inverse association between type } 1 \\
\text { diabetes and prevalence of AD in } \\
\text { childhood }\end{array}$ \\
\hline & Fsadni et al. [105] & Ecological study & $\begin{array}{l}\text { Type } 1 \text { diabetes prevalence from the Mondiale Project } \\
\text { Group and prevalence } \\
\text { of AD from the ISAAC study }\end{array}$ & $\begin{array}{l}\text { Positive association between type } 1 \\
\text { diabetes and prevalence of AD in } \\
\text { childhood }\end{array}$ \\
\hline & Gazit et al. [106] & Case-control study & $\begin{array}{l}\text { Clinical diagnoses of type } 1 \text { diabetes and atopic } \\
\text { dermatitis }\end{array}$ & $\begin{array}{l}\text { No association between type } 1 \\
\text { diabetes and prevalence of AD in } \\
\text { childhood }\end{array}$ \\
\hline & $\begin{array}{l}\text { Thomsen et al. } \\
\text { [100] }\end{array}$ & Danish twin study & $\begin{array}{l}\text { Hospital discharge diagnosis of type } 2 \text { diabetes } \\
\text { and positive response to atopic dermatitis on } \\
\text { questionnaire }\end{array}$ & $\begin{array}{l}\text { Inverse association between type } \\
2 \text { diabetes and prevalence of } \mathrm{AD} \\
\text { in adults in univariate models; } \\
\text { though, not significant in } \\
\text { multivariate models }\end{array}$ \\
\hline $\begin{array}{l}\text { Erectile } \\
\text { dysfunction }\end{array}$ & Chung et al. $[128 \bullet \bullet]$ & $\begin{array}{l}\text { Taiwanese population-based } \\
\text { case-control study }\end{array}$ & $\begin{array}{l}\text { Newly diagnosed erectile dysfunction } \\
\text { and history of atopic dermatitis }\end{array}$ & $\begin{array}{l}\text { Association between erectile } \\
\text { dysfunction } \\
\text { and history of AD in adults, } \\
\text { even after controlling for obesity, } \\
\text { hypertension, and diabetes }\end{array}$ \\
\hline \multirow[t]{2}{*}{ Fatty liver } & Kimata [132] & Case-control study & $\begin{array}{l}\text { Diagnosis of AD clinically and } \\
\text { fatty liver by ultrasound }\end{array}$ & $\begin{array}{l}\text { Association between } \mathrm{AD} \text { and } \\
\text { fatty liver in children }\end{array}$ \\
\hline & Kimata [131] & $\begin{array}{l}\text { Hospital-based incidence } \\
\text { study }\end{array}$ & $\begin{array}{l}\text { Diagnosis of AD clinically and } \\
\text { fatty liver by ultrasound }\end{array}$ & $\begin{array}{l}\text { Association between } \mathrm{AD} \text { and } \\
\text { fatty liver in children }\end{array}$ \\
\hline
\end{tabular}

account for the rapidly rising prevalence of $\mathrm{AD}$ in the United States and other developed countries.
It is well accepted that certain infectious exposures may decrease the risk of developing AD. This is referred to as the 
"hygiene hypothesis," which states that certain infections and exposures can help guide the immature immune system away from a pro-atopic or inflammatory state [17]. We previously reported that exposure to varicella zoster virus in early childhood was associated with a lower odds of developing AD [18], asthma, and hay fever, as well as decreased serum immunoglobulin E (IgE), allergic sensitization, and persistent alterations of leukocyte subsets [19].

In contrast, some infections might play a pathogenic role in AD. A study of 451 human immunodeficiency virus (HIV)infected children and 227 HIV-exposed but uninfected children and adolescents found that $\mathrm{AD}$ was significantly more common in HIV-infected children (20\% vs. $12 \%$ ) [20]. A cross-sectional study of 306 Ethiopian children age 1-5 years found that history of malaria, infection with the intestinal parasite Trichuris, and use of piped water as opposed to river water were all associated with increased risk of AD [21]. The authors also noted a lack of relationship of AD to family size, crowding in the home, or breast feeding [21].

\section{Comorbidities of Atopic Dermatitis}

\section{Cutaneous Infection}

Patients with AD have increased colonization with Staphylococcus (S.) aureus and have a higher risk of developing bacterial (S. aureus) and viral infections (e.g., eczema herpeticum, warts, molluscum) [22]. In an early study of bacterial colonization of flexural dermatitic skin, S. aureus was found to colonize $91 \%$ of samples and occurred at much higher densities than normal skin [23]. Furthermore, increasing severity of dermatitis was found to have a linear increase in $S$. aureus colony and decreased diphtheroid counts [24]. Recently, more sophisticated bacterial gene sequencing studies revealed that $\mathrm{AD}$ flares were associated with increased S. aureus and S. epidermidis and decreased overall microbial diversity [25•]. AD treatment with emollients, topical corticosteroids, and bleach baths resulted in decreased $S$. aureus and increased microbial diversity, including Streptococcus, Propionibacterium, and Corynebacterium species even before clinical improvement [25•].

Recent attention has been paid to the pathogenic role of defects of toll-like receptor 2 (TLR2) and other pathways of the innate immune system in $\mathrm{AD}$ and associated infections (reviewed in [26••]). TLR2 recognizes peptidoglycan and lipoteichoic acid, components of the cell wall of $S$. aureus and other gram-positive bacteria [27]. TLR2 also can recognize lipopolysaccharide on some gram-negative bacteria, as well as fungi and possibly even herpes viruses [28, 29]. In a study of 78 patients with mild to severe AD and 39 agematched healthy controls, it was found that genetic polymorphisms of TLR2 occurred in $11.5 \%$ of AD patients and only $2.5 \%$ of controls, and TLR 2 polymorphism was associated with more severe AD [30]. Thus, some patients with $\mathrm{AD}$ have impaired aberrancies of innate immunity that may predispose them to increased microbial colonization and infection, aside from skin barrier defects. It is interesting that obesity is associated with numerous effects on the innate immune system, including TLR2 expression (see below). Thus, it is possible that obesity predisposes $\mathrm{AD}$ patients to even higher risk of cutaneous infections.

\section{Asthma}

$\mathrm{AD}$ is associated with a number of comorbid health conditions. In particular, children with $\mathrm{AD}$ are more likely to develop asthma followed by hay fever as they grow older, termed the "atopic march" [31]. Ricci et al. (2006) performed a retrospective study of 252 Italian children with $\mathrm{AD}$ and a follow-up questionnaire 13-22 years later. They found that as the children grew older, the $\mathrm{AD}$ disappeared in $60 \%$, but asthma (34\%) and rhinoconjunctivitis (57\%) subsequently developed; the appearance of asthma occurred in children with severe AD [32]. The Multicenter Allergy Study, a German birth cohort, found that children with AD in the first 2 years of life were more likely to have wheeze at age 7 years if they had severe disease and atopic sensitization [33]. A systematic review of 13 prospective studies found that one out of three children with $\mathrm{AD}$ will develop asthma during later childhood [34]. The Tasmanian Longitudinal Health Study followed a cohort of 8,583 Australian 7-year-old children from 1968 until 2004 and found that childhood eczema was associated with significantly increased incidence of asthma in childhood, preadolescence, adolescence, and adult life [35]. A subsequent study from this cohort found that childhood eczema predicts atopic but not nonatopic asthma in adulthood [36].

\section{Rhinoconjunctivitis}

A cross-sectional study of 2,270 U.S. children with physician-diagnosed $\mathrm{AD}$ found that $38 \%$ had the "atopic triad," including asthma and rhinitis [37]. A prospective study of 94 infants and toddlers with AD until age 7 years found that $45 \%$ developed allergic rhinitis [38]. In a German Multicenter Atopy study, 1,314 newborns were recruited and analyzed, and of this group, 499 infants were at increased risk of atopic disease [33]. Their results showed that disease severity and atopic sensitization are major determinants of increased risk of subsequent wheeze or bronchial hyperreactivity; in contrast, early AD without these cofactors constituted no increased risk of subsequent wheeze.

\section{Atopy}

In a nested case-control study of 2,201 East German schoolchildren age 5-14 years, $75 \%$ of children with $\mathrm{AD}$ had $\geq 1$ 
positive radioallergosorbent test (RAST) compared with only $36 \%$ of children without eczema [39]. Prevalence of allergic sensitization also was associated with AD severity [39]. A study of 116 adults with $\mathrm{AD}$ and 93 nonatopic controls found that serum IgE concentrations were higher in subjects with $\mathrm{AD}$, particularly severe disease with more flares [40].

A paucity of studies have examined the prevalence of food allergies in AD. Silverberg and Simpson recently analyzed a U.S. population-based parental questionnaire study found a much higher prevalence of food allergies in children with $\mathrm{AD}$ compared with no $\mathrm{AD}(15.1 \%$ vs. $3.6 \%)$ [41]. Similarly, a randomized, double-blind, U.S. multicentered study of 1,087 infants with $\mathrm{AD}$ treated with pimecrolimus found a $15.7 \%$ prevalence of food allergies in children with $\mathrm{AD}$ [42]. Some studies using food challenges ("gold standard" for diagnosing food allergies) found even higher prevalence of type I mediated food allergies (37-56\%); however, those studies were not population-based and suffered from selection bias of more severe cases of $\mathrm{AD}$ [43-45]. On the other hand, a study of 8,206 children and adults in the National Health and Nutrition Examination Survey (NHANES) 2005-2006 study examined allergenspecific serum IgE levels and found positive specific-IgE to food allergens in $17.8 \%$ of participants, and only $1.9 \%$ with high specific-IgE levels indicating likely food allergy [46]. However, the study included more adults than children, age-related differences of food allergies were not explored in $\mathrm{AD}$, and history of diagnosed food allergy was not explored [46].

\section{Obesity and Diabetes}

\section{Epidemiology of Obesity and Diabetes}

The prevalence of obesity in the United States and other developed countries has steadily increased during the past 30 years. Obesity affected $10 \%$ of U.S. adults in 1980 but has now more than tripled to $35 \%$ in 2010 [47, 48]. Similarly, obesity in children increased from 5-7\% in 1980 to $16.9 \%$ in 2010 [49]. It is estimated that $50-51 \%$ of adult men and $45-52 \%$ of women in the United States will be obese by the year 2030 [50]. Similarly, the prevalence of obesity in the United Kingdom has more than doubled from $8 \%$ of women and $6 \%$ of men in 1980 to $21 \%$ of women and $17 \%$ of men in 1998 [51] and is estimated to further increase to $41-48 \%$ in men and $35-$ $43 \%$ in women [50]. The number of obese people worldwide by the year 2030 is estimated to be 1.12 billion [52].

The prevalence of diabetes in U.S. adults aged $\geq 20$ years is estimated to be $11.3 \%$, and $26.9 \%$ in aged $\geq 65$ years [53]. Based on data from the NHANES III (1988-1994) and
2010 study, the prevalence of diagnosed diabetes (type 1 or 2) in U.S. children aged 12-19 years was estimated to be $0.4 \%$ and $0.26 \%$, respectively $[53,54]$. Children with type 2 diabetes are most commonly aged 10-19 years, obese, insulin-resistant, with a family history of type 2 diabetes and elevated glycosylated hemoglobin levels (10-12\%) [54].

Obesity and diabetes are associated with increased cardiovascular disease, cancer, and many other chronic health conditions. The increasing prevalence of obesity and to a lesser extent diabetes during the past 30 years coincides with the rising prevalence of $\mathrm{AD}$, suggesting that there may be a relationship between them.

\section{Obesity and Asthma}

Multiple large-scale epidemiological studies demonstrated that obesity is a risk factor for atopic disorders, including asthma and atopy. A cross-sectional study of 7,367 children aged 4-17 years from the NHANES III (1988-1994) survey found a significantly higher prevalence of asthma and atopy with increased body mass index (BMI) [55]. Similarly, studies from the United Kingdom, Australia, Bavaria, and Sweden have all shown elevated BMI, overweight, and/or obesity in children with asthma [56-59]. Most of these studies observed the association between obesity and asthma in both boys and girls [56, 57, 59], whereas only one found it to be female gender-specific [58].

Similarly, obesity in adulthood is associated with increased asthma [60-67] and airway hyperactivity [64], poorer asthma control, asthma-specific quality of life, and having more asthma-related healthcare utilization [60-63]. Fitzpatrick et al. conducted a clinical study of 246 adult allergy patients in New York City and found that obesity was associated with significantly higher odds of developing atopic asthma, more severe asthma, and markers of poorer lung function (decreased peak flow, forced expiratory volume in 1 second (FEV1), and forced vital capacity (FVC)), increased asthma exacerbations requiring oral corticosteroids, poorer long-term asthma control requiring inhaled corticosteroids, and increased serum IgE compared with atopic nonasthmatic controls [68].

\section{Obesity and Atopy}

A study of 4,111 U.S. children aged 2-19 years from the National Health and Nutrition Examination Survey (NHANES) 2005-2006 study found that serum IgE levels and atopy were higher among obese children, with a predominance of food allergy sensitization [69•]. Elevated CRP levels are associated with total IgE levels, atopy, and food sensitization [69•].

There are conflicting data regarding the role of obesity in adult atopy. Some studies found an association between 
atopy and central and/or general obesity in adults [70-72], whereas others did not [73-76].

Obesity and Rhinoconjunctivitis

Multiple studies found no association between obesity and rhinoconjunctivitis in either children [58,59, 77-79] or adults [80]. One study of 10,667 Finnish university students aged 18-25 years found that obesity was significantly associated with rhinoconjunctivitis in women but not men [81].

\section{Obesity and Atopic Dermatitis}

\section{Secondary Outcomes Data}

Several studies of AD as a secondary outcome found conflicting results regarding about an association with BMI, with asthma or atopy as the primary study outcomes (Table 1) [58, 59, 82, 83]. A questionnaire-based study to 38,955 Korean children age 6-15 years found a significant association between increasing BMI and eczema [84]. Another questionnaire-based case-control study of 457 Swedish adolescents (12 years) found an association between overweight with history of wheezing and eczema in wheezing children [59].

In contrast, a questionnaire-based study of parents of 9,357 children aged 5-6 years in rural areas in Bavaria found an association between obesity and ever-asthma in girls, but not eczema in boys or girls [58]. A questionnairebased study of 2,926 adolescents aged 13-14 years in the Republic of Macedonia found no association between being overweight and eczema [83]. Last, a questionnaire-based study of 8,624 children aged 6-7 years and 13-14 years in Mexico City as part of The International Study of Asthma and Allergies in Childhood (ISAAC) Phase III study found that obesity in 6- to 7-year-old girls and 13-14-year-old boys was associated with less eczema [82]. (Note: ISAAC Phase I study enrolled 721,601 children aged 6-7 years and 13-14 years in 156 collaborating centers in 56 countries between 1993-1995. ISAAC Phase II enrolled 53,383 children aged 10-12 years in 30 centers in 22 selected countries starting in 1998. ISAAC Phase III was a repeat of Phase I to examine time trends of allergic disease and enrolled 1,187,496 children from 237 collaborating centers in 98 countries between 2001-2003.) From these conflicting data, it is difficult to make definitive conclusions about the association between obesity and AD.

\section{Primary Outcomes Data}

During the past 2 years, a number of studies were published that were primarily designed to examine the role of obesity in AD. Silverberg et al. (2011) conducted a retrospective, pediatric practice-based, case-control study that randomly sampled 414 children and adolescents aged 1-21 years with physician-diagnosed AD and 828 age-matched healthy control subjects [85••]. We found that obesity in childhood was associated with a twofold higher odds of subsequently developing $\mathrm{AD}$. The increased odds of developing $\mathrm{AD}$ occurred particularly in children who had prolonged duration ( $>2.5$ years) and early onset (ages $0-2$ or $2-5$ years) of obesity. Obese children with AD had more severe disease and frequent pediatrician visits devoted to $\mathrm{AD}[85 \bullet \cdot]$. Although the study was retrospective, the data were longitudinal and showed that obesity preceded the diagnosis of $\mathrm{AD}$.

Another study conducted by Silverberg was a prospective, allergy practice-based study using patient questionnaires, height and weight measurements, and skin-prick testing in 2,090 adults [86]. AD was defined using a composite of answering yes to eczema and yes to family history of atopic disorders on questionnaire and having at least one positive skin-prick test. We found that obesity in adults is associated with increased odds of $\mathrm{AD}$, but not eczema or atopy alone [86]. However, obesity conferred a smaller risk of $A D$ in adults (odds ratio $(\mathrm{OR})=1.43$ ) than in the abovementioned pediatric cohort $(\mathrm{OR}=2.15$ for obesity at any age, $\mathrm{OR}=15.1$ for onset of obesity in the first 2 years of life).

The Manchester Allergy and Asthma Study prospectively followed 731 children from a birth-cohort at age 3, 5, and 8 years using parental questionnaires and height and weight measurements $[87 \bullet \bullet]$. They found that increasing BMI zscore was significantly associated with increased odds of physician-diagnosed eczema at age 5 and 8 years [87••].

In a parental-questionnaire study of 45,520 Japanese schoolchildren age 7-15 years, increasing BMI was associated with $\mathrm{AD}[88 \bullet \bullet$. Furthermore, obesity was associated with more severe, but not higher, AD prevalence [88••].

A study of 13,153 Spanish children from a subset of the ISAAC Phase 3 questionnaire-study also found that obesity was associated with increased odds of AD [89 • $]$. A crosssectional study of 5,351 Taiwanese children age 4-18 years who participated in the ISAAC study also found that obesity was associated with ever- and current-eczema [90].

All of these studies used BMI to determine obesity, rather than measurements of abdominal/truncal obesity. It is theoretically possible that the association of obesity with $\mathrm{AD}$ is even stronger with abdominal obesity, given the strong associations with numerous medical disorders and health outcomes [91-96]. Nevertheless, these studies demonstrate a strong association between childhood obesity and AD both in the United States and internationally.

\section{Obesity and Hand Dermatitis}

A recent questionnaire-based study 27,793 Swedish adults aged 18-64 years found a significant association between 
obesity and the prevalence of hand dermatitis in both men and women [97]. It is likely that a significant subset of respondents had atopic hand dermatitis. However, there are other phenotypes of hand dermatitis, such as chronic fissured, allergic, and irritant hand dermatitis, which occur in absence of atopic phenotype and have distinct FLG mutations [98, 99].

\section{Diabetes and Asthma}

A study of 34,782 Danish adult twins aged 20-71 years found that diagnosis of type 2 diabetes was associated with history of asthma in both men and women, even after adjusting for BMI and other confounding variables [100]. A retrospective, longitudinal cohort study using the electronic records from Kaiser-Permanente in northern California found that the incidence of asthma was higher in diabetics than nondiabetics (0.48 vs. 0.22 per 1,000 person-years) [101].

\section{Diabetes and Atopic Dermatitis}

There are conflicting studies about an association between $\mathrm{AD}$ and type 1 diabetes. A German population-based study of 760 children newly diagnosed with type 1 diabetes and 1,871 age-, sex-, and residence-matched controls found an inverse association with $\mathrm{AD}$ but not with asthma or rhinoconjunctivitis [102]. In a study of 54,530 Danish twins aged 3-71 years found that diagnosis of type 1 diabetes was associated with decreased AD [103], Similarly, a case-control study of 339 children with type 1 diabetes and 985 controls an inverse association between $\mathrm{AD}$ and type 1 diabetes, independent of mutations in the HLA-DQ, CTLA4, and PTPN22 genes [104].

In contrast, an ecologic study design using merged data from the ISAAC and Diabetes Mondiale Project Group found that type 1 diabetes was associated with $\mathrm{AD}$ and wheeze in adolescents aged 13-14 years [105]. Finally, a case-control study of 65 Israeli children with type 1 diabetes and 74 nondiabetic controls found no association with eczema, other atopic diseases or total and specific serum $\operatorname{IgE}$ levels [106].

Little is known about the relationship between type 2 diabetes and AD. The abovementioned Danish twins study found that type 2 diabetes was associated with a lower prevalence of $\mathrm{AD}$ compared with nondiabetics (3.2\% vs. $6.1 \%$ ), although the association was not significant after adjusting for confounders [100].

\section{Mechanism of Association between AD and Metabolic Factors}

The mechanism(s) behind the association of metabolic factors and $\mathrm{AD}$ is unknown. Although the association of $\mathrm{AD}$ and FLG mutations is now well established, it is not clear how obesity interacts with such genetic predisposition. One possibility is that FLG and other genetic mutations involved in $\mathrm{AD}$ result in both an $\mathrm{AD}$ phenotype and increased risk for obesity and its sequel. Alternatively, obesity may be independent of FLG mutations and acts as a trigger in an already genetically predisposed person. It is therefore possible that obesity may act as a trigger in other disorders associated with FLG mutations. In fact, most of the cross-sectional studies are not able to distinguish between these two options. The pediatricpractice based study of Silverberg et al. [85•*] and Manchester Allergy and Asthma Study [87••] both followed children over an extended period of time. Thus, they were able to show that the obesity clinically preceded the AD well in advance, suggesting that obesity is a trigger or exacerbating for $\mathrm{AD}$, and not merely an epiphenomenon. There is growing use of the term "overweight hypothesis" [83], which states that being overweight or obese early in childhood may guide the immature immune system toward a pro-atopic or inflammatory state.

There is a strong relationship between adiposity and the innate immune system. Multiple TLRs (TLR1-5, 7, and 9) are expressed on adipocytes, at least some of which appear to be functionally active [107-110]. High levels of free fatty acids from obesity and glucose from diabetes activate the innate immune system, with upregulated TLR expression that correlates with insulin resistance and increased inflammatory cytokine release in macrophages [111-113].

Obesity also impacts a number of inflammatory cytokines, cellular pathways. Tumor necrosis factor (TNF) alpha and interleukin (IL)-6 are expressed by macrophages [114] and cytotoxic T cells [115] in adipose tissue [114]. TNF- $\alpha$, IL-6 [116], interferon (IFN)- $\gamma$, and IL-2 $[117,118]$ are all upregulated by the adipokine leptin. Leptin also polarizes $\mathrm{T}$ cells toward a T-helper 1 (Th1) cytokine profile [117]. Leptin also induces proliferation and activation of circulating monocytes [119] and CD4+ and CD8+ T cells [118] and promotes neutrophil chemotaxis $[120,121]$.

Adipokines may play an important role in allergic inflammation. Nagel et al. found a disease-specific association between low adiponectin levels and $\mathrm{AD}$ [122]. Adiponectin levels tend to be lower in obesity [123]. Leptin is an adipokine that is upregulated in obesity. Leptin has been shown to induce eosinophils in vitro to upregulate expression of adhesion molecule ICAM-1 and CD18, stimulate chemokinesis, and induce the release of IL-1 $\beta$, IL-6, IL-8, growthrelated oncogene- $\alpha$, and MCP-1 [124]. Leptin may play a role in the pathogenesis of allergic asthma [125]. A study of 25 children with $\mathrm{AD}$ and 25 age-matched nonatopic controls found increased serum leptin levels in AD [126]. However, another study of 20 children aged $1-8$ years with $A D$ and 20 age-matched controls found no differences of leptin levels in $\mathrm{AD}$ [127]. It is likely that the mechanism of association between obesity and $\mathrm{AD}$ is multifactorial and may include any and all of the above pathways. 


\section{Erectile Dysfunction and Atopic Dermatitis}

A recent population-based study of 23,982 subjects from the Taiwan National Health Insurance program found that erectile dysfunction (ED) was associated with a higher prevalence of AD than non-ED controls (10.6\% vs. $6.7 \%$ ) [128••]. AD was associated with higher odds of ED even after controlling for obesity, hypertension, and diabetes [128••]. This novel association is likely related to a combination of factors, including obesity and diabetes, stress, and lifestyle factors. A study of 36 adult $\mathrm{AD}$ patients with $\mathrm{ED}$ found that viewing humorous films improved their ED, increased serum testosterone, and decreased serum estradiol 4 days later [129]. This study suggests that there is a psychogenic component of ED in AD. However, $\mathrm{ED}$ in $\mathrm{AD}$ patients may have a neuropathic or vascular occlusive component secondary to comorbidities (e.g., obesity and/ or diabetes).

\section{Fatty Liver and AD}

Several studies by Kimata showed an association between fatty liver and $\mathrm{AD}$. Children with $\mathrm{AD}$ were found to have increased fatty liver [130-132]. Children with AD had increased serum leptin levels and even higher leptin levels in $\mathrm{AD}$ with fatty liver [126]. Fatty liver also was associated with increased skin-prick test positivity [133]. However, these associations have yet to be verified in humans by other authors. In NC/Nga mice (animal model of AD [134]), development of AD-like skin lesions was associated with reduced glucose levels and altered transcription of lipid catabolism genes that might lead to cholesterol accumulation in liver [135]. It is possible that the association between fatty liver and $\mathrm{AD}$ is secondary to circulating free fatty acids in chronic obesity.

\section{Conclusions}

The associations between $\mathrm{AD}$, obesity, and other metabolic factors have important clinical ramifications. These associations highlight the importance of maintaining ideal BMI, especially during early childhood, and suggest that weight loss may actually improve AD in some children. To date, no studies have examined the role of weight loss in either highrisk children for prevention of $\mathrm{AD}$ or the treatment of children with AD. Previous studies found a significant improvement of allergic asthma with weight loss [136, 137]. Future studies are needed to elucidate whether weight loss and dietary modification can impact incidence and severity of AD. Finally, they underscore the profound impact that $\mathrm{AD}$ has on overall health. It is important to recognize these comorbidities and diagnose them early to prevent the longterm harmful sequelae.
Disclosures The authors reported no potential conflicts of interest relevant to this article. Part of the data was reviewed at the American Academy of Dermatology 2011 Summer Meeting, "What's Hot in Pediatric Dermatology Symposium,” August 7, 2011.

\section{References}

Papers of particular interest, published recently, have been highlighted as:

- Of importance

•• Of major importance

1. Ellis CN, Drake LA, Prendergast MM, Abramovits W, Boguniewicz M, Daniel CR, et al. Cost of atopic dermatitis and eczema in the United States. J Am Acad Dermatol. 2002;46(3):361-70.

2. Wuthrich B. Clinical aspects, epidemiology, and prognosis of atopic dermatitis. Ann Allergy Asthma Immunol. 1999;83 (5):464-70. doi:10.1016/S1081-1206(10)62852-9.

3. Wuthrich B, Schmid-Grendelmeier P. The atopic eczema/dermatitis syndrome. Epidemiology, natural course, and immunology of the IgE-associated ("extrinsic") and the nonallergic ("intrinsic") AEDS. J Investig Allergol Clin Immunol. 2003;13(1):1-5.

4. - Shaw TE, Currie GP, Koudelka CW, Simpson EL. Eczema prevalence in the United States: data from the 2003 National Survey of Children's Health. J Invest Dermatol. 2011;131 (1):67-73. doi:10.1038/jid.2010.251. U.S. population-based study of the prevalence and determinants of childhood atopic dermatitis.

5. Irvine AD, McLean WH. Breaking the (un)sound barrier: filaggrin is a major gene for atopic dermatitis. J Invest Dermatol. 2006;126(6):1200-2. doi:10.1038/sj.jid.5700365.

6. O'Regan GM, Irvine AD. The role of filaggrin loss-of-function mutations in atopic dermatitis. Curr Opin Allergy Clin Immunol. 2008;8(5):406-10. doi:10.1097/ACI.0b013e32830e6fb2.

7. O'Regan GM, Sandilands A, McLean WH, Irvine AD. Filaggrin in atopic dermatitis. J Allergy Clin Immunol. 2008;122(4):68993. doi:10.1016/j.jaci.2008.08.002.

8. Palmer CN, Irvine AD, Terron-Kwiatkowski A, Zhao Y, Liao H, Lee SP, et al. Common loss-of-function variants of the epidermal barrier protein filaggrin are a major predisposing factor for atopic dermatitis. Nat Genet. 2006;38(4):441-6. doi:10.1038/ng1767.

9. Rodriguez E, Baurecht H, Herberich E, Wagenpfeil S, Brown SJ, Cordell HJ, et al. Meta-analysis of filaggrin polymorphisms in eczema and asthma: robust risk factors in atopic disease. J Allergy Clin Immunol. 2009;123(6):1361-70. doi:10.1016/ j.jaci.2009.03.036

10. Sandilands A, O'Regan GM, Liao H, Zhao Y, TerronKwiatkowski A, Watson RM, et al. Prevalent and rare mutations in the gene encoding filaggrin cause ichthyosis vulgaris and predispose individuals to atopic dermatitis. J Invest Dermatol. 2006;126(8):1770-5. doi:10.1038/sj.jid.5700459.

11. Sandilands A, Terron-Kwiatkowski A, Hull PR, O'Regan GM, Clayton TH, Watson RM, et al. Comprehensive analysis of the gene encoding filaggrin uncovers prevalent and rare mutations in ichthyosis vulgaris and atopic eczema. Nat Genet. 2007;39 (5):650-4. doi:10.1038/ng2020.

12. Weidinger S, Illig T, Baurecht H, Irvine AD, Rodriguez E, DiazLacava A, et al. Loss-of-function variations within the filaggrin gene predispose for atopic dermatitis with allergic sensitizations. J Allergy Clin Immunol. 2006;118(1):214-9. doi:10.1016/ j.jaci.2006.05.004 
13. Baurecht H, Irvine AD, Novak N, Illig T, Buhler B, Ring J, et al. Toward a major risk factor for atopic eczema: meta-analysis of filaggrin polymorphism data. J Allergy Clin Immunol. 2007;120 (6):1406-12. doi:10.1016/j.jaci.2007.08.067.

14. Chavanas S, Bodemer C, Rochat A, Hamel-Teillac D, Ali M, Irvine $\mathrm{AD}$, et al. Mutations in SPINK5, encoding a serine protease inhibitor, cause Netherton syndrome. Nat Genet. 2000;25 (2):141-2. doi:10.1038/75977.

15. Nishio Y, Noguchi E, Shibasaki M, Kamioka M, Ichikawa E, Ichikawa $\mathrm{K}$, et al. Association between polymorphisms in the SPINK5 gene and atopic dermatitis in the Japanese. Genes Immun. 2003;4(7):515-7. doi:10.1038/sj.gene.6363889.

16. Weidinger S, Baurecht H, Wagenpfeil S, Henderson J, Novak N, Sandilands A, et al. Analysis of the individual and aggregate genetic contributions of previously identified serine peptidase inhibitor Kazal type 5 (SPINK5), kallikrein-related peptidase 7 (KLK7), and filaggrin (FLG) polymorphisms to eczema risk. J Allergy Clin Immunol. 2008;122(3):560-8. doi:10.1016/ j.jaci.2008.05.050.

17. Strachan DP. Hay fever, hygiene, and household size. BMJ. 1989;299(6710):1259-60.

18. Silverberg JI, Norowitz KB, Kleiman E, Silverberg NB, Durkin HG, Joks R, et al. Association between varicella zoster virus infection and atopic dermatitis in early and late childhood: a case-control study. J Allergy Clin Immunol. 2010;126(2):300-5. doi:10.1016/j.jaci.2010.05.041

19. Silverberg JI, Kleiman E, Silverberg NB, Durkin HG, Joks R, Smith-Norowitz TA. Chickenpox in childhood is associated with decreased atopic disorders, IgE, allergic sensitization, and leukocyte subsets. Pediatr Allergy Immunol. 2012;23(1):50-8. doi:10.1111/ j.1399-3038.2011.01224.x.

20. Siberry GK, Leister E, Jacobson DL, Foster SB, Seage 3rd GR, Lipshultz SE, et al. Increased risk of asthma and atopic dermatitis in perinatally HIV-infected children and adolescents. Clin Immunol. 2012;142(2):201-8. doi:10.1016/j.clim.2011.10.005.

21. Haileamlak A, Dagoye D, Williams H, Venn AJ, Hubbard R, Britton $\mathrm{J}$, et al. Early life risk factors for atopic dermatitis in Ethiopian children. J Allergy Clin Immunol. 2005;115(2):370 6. doi:10.1016/j.jaci.2004.10.024.

22. Bolognia J. Dermatology. 2nd ed. St. Louis: Mosby Elsevier; 2008.

23. Leyden JJ, Marples RR, Kligman AM. Staphylococcus aureus in the lesions of atopic dermatitis. Br J Dermatol. 1974;90(5):525-30.

24. Williams RE, Gibson AG, Aitchison TC, Lever R, Mackie RM. Assessment of a contact-plate sampling technique and subsequent quantitative bacterial studies in atopic dermatitis. Br J Dermatol. 1990;123(4):493-501.

25. - Kong HH, Oh J, Deming C, Conlan S, Grice EA, Beatson MA, et al. Temporal shifts in the skin microbiome associated with disease flares and treatment in children with atopic dermatitis. Genome Res. 2012;22(5):850-9. doi:10.1101/gr.131029.111. Bacterial gene sequencing study demonstrating increased S. Aureus and decreased microbial diversity in AD flares, which reversed with AD treatment.

26. •• De Benedetto A, Agnihothri R, McGirt LY, Bankova LG, Beck LA. Atopic dermatitis: a disease caused by innate immune defects? J Invest Dermatol. 2009;129(1):14-30. doi:10.1038/ jid.2008.259. Review of recent discoveries of the role of the innate immune system, antimicrobial peptides and toll-like receptors in atopic dermatitis.

27. Schwandner R, Dziarski R, Wesche H, Rothe M, Kirschning CJ. Peptidoglycan- and lipoteichoic acid-induced cell activation is mediated by toll-like receptor 2. J Biol Chem. 1999;274 (25): $17406-9$

28. Sato A, Linehan MM, Iwasaki A. Dual recognition of herpes simplex viruses by TLR 2 and TLR9 in dendritic cells. Proc Natl
Acad Sci U S A. 2006;103(46):17343-8. doi:10.1073/ pnas.0605102103.

29. Zahringer $U$, Lindner $B$, Inamura $S$, Heine $H$, Alexander C. TLR2 - promiscuous or specific? A critical re-evaluation of a receptor expressing apparent broad specificity. Immunobiology. 2008;213 (3-4):205-24. doi:10.1016/j.imbio.2008.02.005.

30. Ahmad-Nejad P, Mrabet-Dahbi S, Breuer K, Klotz M, Werfel T, Herz U, et al. The toll-like receptor 2 R753Q polymorphism defines a subgroup of patients with atopic dermatitis having severe phenotype. J Allergy Clin Immunol. 2004;113(3):565-7.

31. Spergel JM, Paller AS. Atopic dermatitis and the atopic march. J Allergy Clin Immunol. 2003;112(6 Suppl):S118-27. doi:10.1016/ j.jaci.2003.09.033.

32. Ricci G, Patrizi A, Baldi E, Menna G, Tabanelli M, Masi M. Long-term follow-up of atopic dermatitis: retrospective analysis of related risk factors and association with concomitant allergic diseases. J Am Acad Dermatol. 2006;55(5):765-71. doi:10.1016/ j.jaad.2006.04.064.

33. Illi S, von Mutius E, Lau S, Nickel R, Gruber C, Niggemann B, et al. The natural course of atopic dermatitis from birth to age 7 years and the association with asthma. J Allergy Clin Immunol. 2004;113(5):925-31. doi:10.1016/j.jaci.2004.01.778.

34. van der Hulst AE, Klip H, Brand PL. Risk of developing asthma in young children with atopic eczema: a systematic review. J Allergy Clin Immunol. 2007;120(3):565-9. doi:10.1016/ j.jaci.2007.05.042.

35. Burgess JA, Dharmage SC, Byrnes GB, Matheson MC, Gurrin LC, Wharton CL, et al. Childhood eczema and asthma incidence and persistence: a cohort study from childhood to middle age. J Allergy Clin Immunol. 2008;122(2):280-5. doi:10.1016/ j.jaci.2008.05.018.

36. Martin PE, Matheson MC, Gurrin L, Burgess JA, Osborne N, Lowe AJ, et al. Childhood eczema and rhinitis predict atopic but not nonatopic adult asthma: a prospective cohort study over 4 decades. J Allergy Clin Immunol. 2011;127(6):1473-9. doi:10.1016/j.jaci.2011.02.041.

37. Kapoor R, Menon C, Hoffstad O, Bilker W, Leclerc P, Margolis DJ. The prevalence of atopic triad in children with physicianconfirmed atopic dermatitis. J Am Acad Dermatol. 2008;58 (1):68-73. doi:10.1016/j.jaad.2007.06.041.

38. Gustafsson D, Sjoberg O, Foucard T. Development of allergies and asthma in infants and young children with atopic dermatitis-a prospective follow-up to 7 years of age. Allergy. 2000;55(3):240-5.

39. Schafer T, Heinrich J, Wjst M, Adam H, Ring J, Wichmann HE. Association between severity of atopic eczema and degree of sensitization to aeroallergens in schoolchildren. J Allergy Clin Immunol. 1999;104(6):1280-4.

40. Wuthrich B. Serum IgE in atopic dermatitis: relationship to severity of cutaneous involvement and course of disease as well as coexistence of atopic respiratory diseases. Clin Allergy. 1978;8 (3):241-8.

41. Silverberg JI, Simpson EL. Eczema severity is associated with multiple comorbid conditions and increased healthcare utilization. J Investig Dermatol. 2012;132(Supplement 1s):S44.

42. Hanifin JM, Boguniewicz M, Eichenfield LF, Schneider LC, Paller AS, Preston JA, et al. A long-term study of safety and allergic comorbidity development in a randomized trial of pimecrolimus cream in infants with atopic dermatitis. J Investig Dermatol. 2010;130(Supplement 1s):S55.

43. Burks AW, James JM, Hiegel A, Wilson G, Wheeler JG, Jones $\mathrm{SM}$, et al. Atopic dermatitis and food hypersensitivity reactions. J Pediatr. 1998;132(1):132-6.

44. Eigenmann PA, Sicherer SH, Borkowski TA, Cohen BA, Sampson HA. Prevalence of IgE-mediated food allergy among children with atopic dermatitis. Pediatrics. 1998;101(3):E8. 
45. Sampson HA, McCaskill CC. Food hypersensitivity and atopic dermatitis: evaluation of 113 patients. J Pediatr. 1985;107 (5):669-75.

46. Liu AH, Jaramillo R, Sicherer SH, Wood RA, Bock SA, Burks $\mathrm{AW}$, et al. National prevalence and risk factors for food allergy and relationship to asthma: results from the National Health and Nutrition Examination Survey 2005-2006. J Allergy Clin Immunol. 2010;126(4):798-806. doi:10.1016/j.jaci.2010.07.026.

47. Flegal KM, Carroll MD, Kit BK, Ogden CL. Prevalence of obesity and trends in the distribution of body mass index among US adults, 1999-2010. JAMA. 2012;307(5):491-7. doi:10.1001/ jama.2012.39.

48. Ogden CL, Carroll MD, Curtin LR, McDowell MA, Tabak CJ, Flegal KM. Prevalence of overweight and obesity in the United States, 1999-2004. JAMA. 2006;295(13):1549-55. doi:10.1001/ jama.295.13.1549.

49. Ogden CL, Carroll MD, Kit BK, Flegal KM. Prevalence of obesity and trends in body mass index among US children and adolescents, 1999-2010. JAMA. 2012;307(5):483-90. doi:10.1001/jama.2012.40.

50. Wang YC, McPherson K, Marsh T, Gortmaker SL, Brown M. Health and economic burden of the projected obesity trends in the USA and the UK. Lancet. 2011;378(9793):815-25. doi:10.1016/ S0140-6736(11)60814-3.

51. House of Commons. Committee of Public Accounts. Tackling obesity in England : Report, together with proceedings of the committee, minutes of evidence and appendices. London; 2001.

52. Kelly T, Yang W, Chen CS, Reynolds K, He J. Global burden of obesity in 2005 and projections to 2030. Int J Obes (Lond). 2008;32(9):1431-7. doi:10.1038/ijo.2008.102.

53. Diabetes Public Health Resource: 2011 National Diabetes Fact Sheet. 2012.

54. Fagot-Campagna A, Pettitt DJ, Engelgau MM, Burrows NR, Geiss LS, Valdez R, et al. Type 2 diabetes among North American children and adolescents: an epidemiologic review and a public health perspective. J Pediatr. 2000;136(5):664-72.

55. von Mutius E, Schwartz J, Neas LM, Dockery D, Weiss ST. Relation of body mass index to asthma and atopy in children: the National Health and Nutrition Examination Study III. Thorax. 2001;56(11):835-8.

56. Figueroa-Munoz JI, Chinn S, Rona RJ. Association between obesity and asthma in 4-11 year old children in the UK. Thorax. 2001;56(2):133-7.

57. Tai A, Volkmer R, Burton A. Association between asthma symptoms and obesity in preschool (4-5 year old) children. J Asthma. 2009;46(4):362-5. doi:10.1080/02770900902759260.

58. von Kries R, Hermann M, Grunert VP, von Mutius E. Is obesity a risk factor for childhood asthma? Allergy. 2001;56(4):318-22.

59. Mai XM, Nilsson L, Axelson O, Braback L, Sandin A, Kjellman NI, et al. High body mass index, asthma and allergy in Swedish schoolchildren participating in the International Study of Asthma and Allergies in Childhood: phase II. Acta Paediatr. 2003;92 (10): $1144-8$.

60. Grammer LC, Weiss KB, Pedicano JB, Kimmel LG, Curtis LS, Catrambone $\mathrm{CD}$, et al. Obesity and asthma morbidity in a community-based adult cohort in a large urban area: the Chicago Initiative to Raise Asthma Health Equity (CHIRAH). J Asthma. 2010;47(5):491-5. doi:10.3109/02770901003801980.

61. Lavoie KL, Bacon SL, Labrecque M, Cartier A, Ditto B. Higher BMI is associated with worse asthma control and quality of life but not asthma severity. Respir Med. 2006;100(4):648-57. doi:10.1016/j.rmed.2005.08.001.

62. Mosen DM, Schatz M, Magid DJ, Camargo Jr CA. The relationship between obesity and asthma severity and control in adults. J Allergy Clin Immunol. 2008;122(3):507-11. doi:10.1016/ j.jaci.2008.06.024.
63. Saint-Pierre P, Bourdin A, Chanez P, Daures JP, Godard P. Are overweight asthmatics more difficult to control? Allergy. 2006;61 (1):79-84. doi:10.1111/j.1398-9995.2005.00953.x.

64. Sharma S, Tailor A, Warrington R, Cheang M. Is obesity associated with an increased risk for airway hyperresponsiveness and development of asthma? Allergy Asthma Clin Immunol. 2008;4 (2):51-8. doi:10.1186/1710-1492-4-2-51.

65. Shore SA. Obesity and asthma: lessons from animal models. J Appl Physiol. 2007;102(2):516-28. doi:10.1152/japplphysiol.00847.2006.

66. Shore SA. Obesity and asthma: cause for concern. Curr Opin Pharmacol. 2006;6(3):230-6. doi:10.1016/j.coph.2006.01.004.

67. Shore SA, Johnston RA. Obesity and asthma. Pharmacol Ther. 2006;110(1):83-102. doi:10.1016/j.pharmthera.2005.10.002.

68. Fitzpatrick S, Joks R, Silverberg JI. Obesity is associated with increased asthma severity and exacerbations, and increased serum immunoglobulin E in inner-city adults. Clin Exp Allergy. 2012;42(5):747-59. doi:10.1111/j.1365-2222.2011.03863.x.

69. • Visness CM, London SJ, Daniels JL, Kaufman JS, Yeatts KB, Siega-Riz AM, et al. Association of obesity with IgE levels and allergy symptoms in children and adolescents: results from the National Health and Nutrition Examination Survey 2005-2006. J Allergy Clin Immunol. 2009;123(5):1163-9. doi:10.1016/ j.jaci.2008.12.1126. Data from the National Health and Nutrition Examination Survey study showing an association between serum IgE levels and obesity.

70. Chen Y, Dales R, Jiang Y. The association between obesity and asthma is stronger in nonallergic than allergic adults. Chest. 2006;130(3):890-5. doi:10.1378/chest.130.3.890.

71. Chen Y, Rennie D, Cormier Y, Dosman J. Association between obesity and atopy in adults. Int Arch Allergy Immunol. 2010;153 (4):372-7. doi:10.1159/000316348.

72. Vieira VJ, Ronan AM, Windt MR, Tagliaferro AR. Elevated atopy in healthy obese women. Am J Clin Nutr. 2005;82 (3):504-9.

73. Flexeder C, Bruske I, Magnussen H, Heinrich J. Association between obesity and atopy in adults? Int Arch Allergy Immunol. 2011;156(1):117-8. doi:10.1159/000322296.

74. Schachter LM, Peat JK, Salome CM. Asthma and atopy in overweight children. Thorax. 2003;58(12):1031-5.

75. Chen Y, Rennie D, Cormier Y, Dosman J. Atopy, obesity, and asthma in adults: the Humboldt study. J Agromedicine. 2009;14 (2):222-7. doi:10.1080/10599240902724051.

76. Ma J, Xiao L, Knowles SB. Obesity, insulin resistance and the prevalence of atopy and asthma in US adults. Allergy. 2010;65 (11):1455-63. doi:10.1111/j.1398-9995.2010.02402.x.

77. Van Gysel D, Govaere E, Verhamme K, Doli E, De Baets F. Body mass index in Belgian schoolchildren and its relationship with sensitization and allergic symptoms. Pediatr Allergy Immunol. 2009;20(3):246-53. doi:10.1111/j.13993038.2008.00774.x.

78. Wang HY, Pizzichini MM, Becker AB, Duncan JM, Ferguson AC, Greene JM, et al. Disparate geographic prevalences of asthma, allergic rhinoconjunctivitis and atopic eczema among adolescents in five Canadian cities. Pediatr Allergy Immunol. 2010;21(5):867-77. doi:10.1111/j.1399-3038.2010.01064.x.

79. Garcia-Marcos L, Canflanca IM, Garrido JB, Varela AL, GarciaHernandez G, Guillen Grima F, et al. Relationship of asthma and rhinoconjunctivitis with obesity, exercise and Mediterranean diet in Spanish schoolchildren. Thorax. 2007;62(6):503-8. doi:10.1136/thx.2006.060020.

80. Braback L, Hjern A, Rasmussen F. Body mass index, asthma and allergic rhinoconjunctivitis in Swedish conscripts-a national cohort study over three decades. Respir Med. 2005;99(8):1010-4. doi:10.1016/j.rmed.2005.02.004.

81. Kilpelainen M, Terho EO, Helenius H, Koskenvuo M. Body mass index and physical activity in relation to asthma and atopic 
diseases in young adults. Respir Med. 2006;100(9):1518-25. doi:10.1016/j.rmed.2006.01.011.

82. Violante R, del Rio Navarro BE, Berber A, Ramirez Chanona N, Baeza Bacab M, Sienra Monge JJ. Obesity risk factors in the ISAAC (International Study of Asthma and Allergies in Childhood) in Mexico City. Rev Alerg Mex. 2005;52(4):141-5.

83. Vlaski E, Stavric K, Isjanovska R, Seckova L, Kimovska M. Overweight hypothesis in asthma and eczema in young adolescents. Allergol Immunopathol (Madr). 2006;34(5):199-205.

84. Lee SI, Shin MH, Lee HB, Lee JS, Son BK, Koh YY, et al. Prevalences of symptoms of asthma and other allergic diseases in korean children: a nationwide questionnaire survey. J Korean Med Sci. 2001;16(2):155-64.

85. •• Silverberg JI, Kleiman E, Lev-Tov H, Silverberg NB, Durkin HG, Joks R, et al. Association between obesity and atopic dermatitis in childhood: a case-control study. J Allergy Clin Immunol. 2011;127(5):1180-6. doi:10.1016/j.jaci.2011.01.063. Clinical study demonstrating that obesity precedes and is associated with greater prevalence, severity and healthcare utilization from atopic dermatitis.

86. Silverberg JI, Silverberg NB, Lee-Wong M. Association between atopic dermatitis and obesity in adulthood. Br J Dermatol. 2012;166(3):498-504. doi:10.1111/j.1365-2133.2011.10694.x.

87. •- Murray CS, Canoy D, Buchan I, Woodcock A, Simpson A, Custovic A. Body mass index in young children and allergic disease: gender differences in a longitudinal study. Clin Exp Allergy. 2011;41 (1):78-85. doi:10.1111/j.1365-2222.2010.03598.x. British birth cohort study that found increased odds of AD with increased BMI.

88. •• Kusunoki T, Morimoto T, Nishikomori R, Heike T, Ito M, Hosoi S, et al. Obesity and the prevalence of allergic diseases in schoolchildren. Pediatr Allergy Immunol. 2008;19 (6):527-34. doi:10.1111/j.1399-3038.2007.00686.x. Japanese questionnaire-based study showing increased prevalence of AD with obesity.

89. •• Suarez-Varela MM, Alvarez LG, Kogan MD, Ferreira JC, Martinez Gimeno A, Aguinaga Ontoso I, et al. Diet and prevalence of atopic eczema in 6 to 7-year-old schoolchildren in Spain: ISAAC phase III. J Investig Allergol Clin Immunol. 2010;20(6):469-75. Cross-section of the International Study of Asthma and Allergies in Childhood Phase III study showing increased odds of AD with obesity.

90. Yao TC, Ou LS, Yeh KW, Lee WI, Chen LC, Huang JL. Associations of age, gender, and BMI with prevalence of allergic diseases in children: PATCH study. J Asthma. 2011;48(5):50310. doi:10.3109/02770903.2011.576743.

91. dos Santos RE, Aldrighi JM, Lanz JR, Ferezin PC, Marone MM. Relationship of body fat distribution by waist circumference, dual-energy X-ray absorptiometry and ultrasonography to insulin resistance by homeostasis model assessment and lipid profile in obese and non-obese postmenopausal women. Gynecol Endocrinol. 2005;21(5):295-301. doi:10.1080/09513590500361937.

92. Valsamakis G, Chetty R, Anwar A, Banerjee AK, Barnett A, Kumar S. Association of simple anthropometric measures of obesity with visceral fat and the metabolic syndrome in male Caucasian and Indo-Asian subjects. Diabet Med. 2004;21 (12):1339-45. doi:10.1111/j.1464-5491.2004.01361.x.

93. Shao J, Yu L, Shen X, Li D, Wang K. Waist-to-height ratio, an optimal predictor for obesity and metabolic syndrome in Chinese adults. J Nutr Health Aging. 2010;14(9):782-5.

94. Lakka HM, Lakka TA, Tuomilehto J, Salonen JT. Abdominal obesity is associated with increased risk of acute coronary events in men. Eur Heart J. 2002;23(9):706-13. doi:10.1053/euhj.2001.2889.

95. Schneider HJ, Glaesmer H, Klotsche J, Bohler S, Lehnert H, Zeiher AM, et al. Accuracy of anthropometric indicators of obesity to predict cardiovascular risk. J Clin Endocrinol Metab. 2007;92(2):589-94. doi:10.1210/jc.2006-0254.
96. Schneider HJ, Klotsche J, Stalla GK, Wittchen HU. Obesity and risk of myocardial infarction: the INTERHEART study. Lancet. 2006;367 (9516):1052. doi:10.1016/S0140-6736(06)68462-6. author reply 4.

97. Anveden Berglind I, Alderling M, Meding B. Life-style factors and hand eczema. Br J Dermatol. 2011;165(3):568-75. doi:10.1111/j.1365-2133.2011.10394.x.

98. Thyssen JP, Ross-Hansen K, Johansen JD, Zachariae C, Carlsen $\mathrm{BC}$, Linneberg A, et al. Filaggrin loss-of-function mutation $\mathrm{R} 501 \mathrm{X}$ and $2282 \mathrm{del} 4$ carrier status is associated with fissured skin on the hands: results from a cross-sectional population study. Br J Dermatol. 2012;166(1):46-53. doi:10.1111/j.13652133.2011.10530.x.

99. Molin S, Vollmer S, Weiss EH, Ruzicka T, Prinz JC. Filaggrin mutations may confer susceptibility to chronic hand eczema characterized by combined allergic and irritant contact dermatitis. Br J Dermatol. 2009;161(4):801-7. doi:10.1111/j.13652133.2009.09245.x.

100. Thomsen SF, Duffy DL, Kyvik KO, Skytthe A, Backer V. Risk of asthma in adult twins with type 2 diabetes and increased body mass index. Allergy. 2011;66(4):562-8. doi:10.1111/j.13989995.2010.02504.x.

101. Ehrlich SF, Quesenberry Jr CP, Van Den Eeden SK, Shan J, Ferrara A. Patients diagnosed with diabetes are at increased risk for asthma, chronic obstructive pulmonary disease, pulmonary fibrosis, and pneumonia but not lung cancer. Diabetes Care. 2010;33(1):55-60. doi:10.2337/dc09-0880.

102. Rosenbauer J, Herzig P, Giani G. Atopic eczema in early childhood could be protective against Type 1 diabetes. Diabetologia. 2003;46(6):784-8. doi:10.1007/s00125-003-1108-6.

103. Thomsen SF, Duffy DL, Kyvik KO, Skytthe A, Backer V. Relationship between type 1 diabetes and atopic diseases in a twin population. Allergy. 2011;66(5):645-7. doi:10.1111/j.13989995.2010.02517.x.

104. Stene LC, Ronningen KS, Bjornvold M, Undlien DE, Joner G. An inverse association between history of childhood eczema and subsequent risk of type 1 diabetes that is not likely to be explained by HLA-DQ, PTPN22, or CTLA4 polymorphisms. Pediatr Diabetes. 2010;11(6):386-93. doi:10.1111/j.13995448.2009.00605.x.

105. Fsadni P, Fsadni C, Fava S, Montefort S. Correlation of worldwide incidence of type 1 diabetes (DiaMond) with prevalence of asthma and atopic eczema (ISAAC). Clin Respir J. 2012;6(1):1825. doi:10.1111/j.1752-699X.2011.00239.x.

106. Gazit V, Tasher D, Hanukoglu A, Landau Z, Ben-Yehuda Y, Somekh E, et al. Atopy in children and adolescents with insulin-dependent diabetes mellitus. Isr Med Assoc J. 2008;10 (12):858-61.

107. Lin Y, Lee H, Berg AH, Lisanti MP, Shapiro L, Scherer PE. The lipopolysaccharide-activated toll-like receptor (TLR)-4 induces synthesis of the closely related receptor TLR-2 in adipocytes. J Biol Chem. 2000;275(32):24255-63. doi:10.1074/ jbc.M002137200.

108. Creely SJ, McTernan PG, Kusminski CM, Fisher M, Da Silva NF, Khanolkar M, et al. Lipopolysaccharide activates an innate immune system response in human adipose tissue in obesity and type 2 diabetes. Am J Physiol Endocrinol Metab. 2007;292(3): E740-7. doi:10.1152/ajpendo.00302.2006.

109. Pietsch J, Batra A, Stroh T, Fedke I, Glauben R, Okur B, et al. Toll-like receptor expression and response to specific stimulation in adipocytes and preadipocytes: on the role of fat in inflammation. Ann N Y Acad Sci. 2006;1072:407-9. doi:10.1196/ annals.1326.021.

110. Vitseva OI, Tanriverdi K, Tchkonia TT, Kirkland JL, McDonnell $\mathrm{ME}$, Apovian CM, et al. Inducible Toll-like receptor and NF-kappaB regulatory pathway expression in human adipose tissue. Obesity (Silver Spring). 2008;16(5):932-7. doi:10.1038/oby.2008.25. 
111. Reyna SM, Ghosh S, Tantiwong P, Meka CS, Eagan P, Jenkinson $\mathrm{CP}$, et al. Elevated toll-like receptor 4 expression and signaling in muscle from insulin-resistant subjects. Diabetes. 2008;57 (10):2595-602. doi:10.2337/db08-0038.

112. Dasu MR, Jialal I. Free fatty acids in the presence of high glucose amplify monocyte inflammation via Toll-like receptors. Am J Physiol Endocrinol Metab. 2011;300(1):E145-54. doi:10.1152/ ajpendo.00490.2010.

113. Dasu MR, Devaraj S, Park S, Jialal I. Increased toll-like receptor (TLR) activation and TLR ligands in recently diagnosed type 2 diabetic subjects. Diabetes Care. 2010;33(4):861-8. doi:10.2337/ dc09-1799.

114. Weisberg SP, McCann D, Desai M, Rosenbaum M, Leibel RL, Ferrante Jr AW. Obesity is associated with macrophage accumulation in adipose tissue. J Clin Invest. 2003;112(12):1796-808. doi:10.1172/JCI19246.

115. Rausch ME, Weisberg S, Vardhana P, Tortoriello DV. Obesity in $\mathrm{C} 57 \mathrm{BL} / 6 \mathrm{~J}$ mice is characterized by adipose tissue hypoxia and cytotoxic T-cell infiltration. Int J Obes (Lond). 2008;32(3):45163. doi:10.1038/sj.ijo.0803744.

116. Kiguchi N, Maeda T, Kobayashi Y, Fukazawa Y, Kishioka S. Leptin enhances $\mathrm{CC}$-chemokine ligand expression in cultured murine macrophage. Biochem Biophys Res Commun. 2009;384 (3):311-5. doi:10.1016/j.bbrc.2009.04.121.

117. Lord GM, Matarese G, Howard JK, Bloom SR, Lechler RI. Leptin inhibits the anti-CD3-driven proliferation of peripheral blood $\mathrm{T}$ cells but enhances the production of proinflammatory cytokines. J Leukoc Biol. 2002;72(2):330-8.

118. Martin-Romero C, Santos-Alvarez J, Goberna R, SanchezMargalet V. Human leptin enhances activation and proliferation of human circulating T lymphocytes. Cell Immunol. 2000;199 (1):15-24. doi:10.1006/cimm.1999.1594.

119. Santos-Alvarez J, Goberna R, Sanchez-Margalet V. Human leptin stimulates proliferation and activation of human circulating monocytes. Cell Immunol. 1999;194(1):6-11. doi:10.1006/cimm.1999.1490.

120. Faggioni R, Feingold KR, Grunfeld C. Leptin regulation of the immune response and the immunodeficiency of malnutrition. FASEB J. 2001;15(14):2565-71. doi:10.1096/fj.01-0431rev.

121. Caldefie-Chezet F, Poulin A, Vasson MP. Leptin regulates functional capacities of polymorphonuclear neutrophils. Free Radic Res. 2003;37(8):809-14.

122. Nagel G, Koenig W, Rapp K, Wabitsch M, Zoellner I, Weiland SK. Associations of adipokines with asthma, rhinoconjunctivitis, and eczema in German schoolchildren. Pediatr Allergy Immunol. 2009;20(1):81-8. doi:10.1111/j.1399-3038.2008.00740.x.
123. Arita Y, Kihara S, Ouchi N, Takahashi M, Maeda K, Miyagawa J, et al. Paradoxical decrease of an adipose-specific protein, adiponectin, in obesity. Biochem Biophys Res Commun. 1999;257(1):79-83.

124. Wong CK, Cheung PF, Lam CW. Leptin-mediated cytokine release and migration of eosinophils: implications for immunopathophysiology of allergic inflammation. Eur J Immunol. 2007;37 (8):2337-48. doi:10.1002/eji.200636866.

125. Sood A. Obesity, adipokines, and lung disease. J Appl Physiol. 2010;108(3):744-53. doi:10.1152/japplphysiol.00838.2009.

126. Kimata H. Elevated serum leptin in AEDS. Allergy. 2002;57(2):179.

127. Bostanci I, Atli O, Celebi N, Tasar A, Alpkarakoc E, Dallar Y. Serum leptin level in children with atopic dermatitis-treated topical steroids. Pediatr Allergy Immunol. 2004;15(3):267-9. doi:10.1111/j.1399-3038.2004.00145.x.

128. •• Chung SD, Keller JJ, Lin HC. Association of erectile dysfunction with atopic dermatitis: a population-based case-control study. J Sex Med. 2012;9(3):679-85. doi:10.1111/j.1743-6109.2011.02587.x. Taiwanese population based study that found a higher prevalence of erectile dysfunction in atopic dermatitis.

129. Kimata H. Short-term improvement of erectile dysfunction by viewing humorous films in patients with atopic dermatitis. J Sex Med. 2008;5(9):2107-10. doi:10.1111/j.1743-6109.2007.00767.x.

130. Kimata H. Increased incidence of fatty liver in non-obese Japanese children under 1 year of age with or without atopic dermatitis. Public Health. 2006;120(2):176-8. doi:10.1016/j.puhe.2005.02.006.

131. Kimata H. Prevalence of fatty liver in non-obese Japanese children with atopic dermatitis. Indian Pediatr. 2005;42(6):587-93.

132. Kimata H. Fatty liver in atopic dermatitis. Allergy. 2001;56 (5):460.

133. Kimata H. Increased SPT, reaction in fatty liver. Allergy. 2001;56 (8):798-9.

134. Suto H, Matsuda H, Mitsuishi K, Hira K, Uchida T, Unno T, et al. NC/Nga mice: a mouse model for atopic dermatitis. Int Arch Allergy Immunol. 1999;120 Suppl 1:70-5.

135. Seino S, Tanaka Y, Honma T, Yanaka M, Sato K, Shinohara N, et al. Atopic dermatitis causes lipid accumulation in the liver of $\mathrm{NC} /$ Nga mouse. J Clin Biochem Nutr. 2012;50(2):152-7. doi:10.3164/jcbn.11-29.

136. Hakala K, Stenius-Aarniala B, Sovijarvi A. Effects of weight loss on peak flow variability, airways obstruction, and lung volumes in obese patients with asthma. Chest. 2000;118 (5):1315-21.

137. Thomas PS, Cowen ER, Hulands G, Milledge JS. Respiratory function in the morbidly obese before and after weight loss. Thorax. 1989;44(5):382-6. 